\title{
Pengembangan E-Modul Menggunakan Inspiring Berbasis Keterampilan Proses Sains Materi Organ Pada Tumbuhan
}

\author{
Fahad $^{1 *}$, Prima Mutia Sari ${ }^{2}$ \\ 1 Universitas Muhammadiyah Prof. DR. Hamka, Jakarta, Indonesia \\ 2Universitas Muhammadiyah Prof. DR. Hamka, Jakarta, Indonesia \\ *Corresponding author: Fahad.muaz10@gmail.com
}

\begin{abstract}
Seeing the condition of education, especially in universities that implement Distance Learning (PPJ) during the Covid-19 pandemic, which makes it a challenge to present easy-to-understand learning. The research aims to develop e-modules in the subject of basic concepts of science 1 material organs in plants and to test the feasibility of the e-modules that have been made so that they can be used during learning. The research method used is research and development (RED) with the ADDIE development model. The instrument used is a validation questionnaire for material experts, media experts and student responses. The data analysis that has been applied is descriptive quantitative and qualitative descriptive data analysis, research results from products developed based on the assessment of material experts get very good criteria with an average percentage score 93\%, assessments from media experts get very good criteria with an average percentage score of $89 \%$, for the results of responses from students getting a percentage score of $87 \%$ with very good criteria, based on the results of data acquisition shows that this e-module is suitable for use as learning resources for 2 nd semester students of PGSD UHAMKA
\end{abstract}

Keyword: android; e-module development; IPA; plant organs

\section{ABSTRAK}

Melihat kondisi Pendidikan khususnya di perguruan tinggi yang menerapkan Pembelajaran Jarak Jauh (PPJ) ketika pandemi Covid-19, yang menjadikan sebuah tantangan untuk menyajikan pembelajaran yang mudah dimengerti. Penelitian bertujuan untuk mengembangkan e-modul pada matakuliah konsep dasar IPA 1 materi organ pada tumbuhan dan menguji kelayakan kelayakan emodul yang telah dibuat supaya bisa dugunakan pada saat pembelajaran metode penelitian yang digunakan adalah research and development (R\&D) dengan model pengembangan ADDIE. Instrumen yang digunakan angket validasi untuk ahli materi, ahli media serta respon mahasiswa, Analisis data yang telah diterapkan adalah analisis data deskriptif kuantitatif dan deskriptif kualitatif, hasil penelitian dari produk yang dikembangkan berdasarkan penilaian dari ahli materi mendapatkan kriteria sangat baik dengan rata-tara skor presentase $93 \%$, penilaian dari ahli media mendapatkan criteria sangat baik dengan presentase rata-rata skor presentase 89\%, untuk hasil respon dari mahasiswa mendapat skor presentase sebesar $87 \%$ dengan kriteria sangat baik, berdasarkan hasil perolehan data menunjukan bahwa e-modul ini layak digunakan sebagai sumber belajar bagi mahasiswa semester 2 PGSD UHAMKA

Kata Kunci: android; ipa; organ tumbuhan; pengembangan e-modul

\section{Pendahuluan}

Indonesia sudah memasuki revolusi industri 4.0 yang berkemajuan dengan sangat pesat yang membuat beberapa bidang harus mengikuti perubahan yang ada, salah satunya pada bidang pendidikan. Teknologi juga mempengaruhi pendidikan yang membuat pendidik mendapatkan ilmu dari berbagai sumber(Priyanthi, Dr. Ketut Agustini, S.Si, and Gede Saindra Santyadiputra, S.T. 2017), tidak hanya dari buku bacaan cetak tetapi juga dari bahan bacaan di internet, pada kondisi seperti ini para pendidik dituntut agar membuat situasi pembelajaran yang lebih menarik dan efektif dengan cara mengembangkan media pembelajaran, dalam prosesnya pembelajaran tidak sekadar menerima pengetahuan saja tapi juga dapat 
memecahkan masalah sebab diharapkan melatih kemampuan berpikir Mahasiswa sehingga dapat mencari informasi, mengumpulkan informasi, memahami serta mengimplementasi pengetahuan yang diperoleh dengan cara berinovasi dari sumber berbagai macam yang ada (Indriani 2020). Hal ini juga terjadi pada pendidikan di perguruan tinggi. Perguruan tinggi merupakan suatu wadah pendidikan yang berperan dalam mengembangkan strategi pemebelajaran. Lembaga tersebut sangat diperlukan dalam membangun peradaban bangsa, terutama untuk membangun nilai-nilai yang sejalan dengan bangsa agar keberagaman diterima sebagai sebuah kekayaan dan tidak dipertentangkan,menurut (Sataloff, Johns, and Kost 2014) Perguruan Tinggi merupakan lembaga pendidikan tertinggi setelah pendidikan dasar dan menengah.

Peserta didik dalam Perguruan Tinggi biasa disebut dengan sebutan mahasiswa. Menurut (Wulan and Abdullah 2014) Mahasiswa merupakan individu yang dewasa, mandiri, cerdas, aktif dan berakal. Mahasiswa juga merupakan individu yang mempunyai potensi dan bakat yang perlu dimantapkan(Sataloff, Johns, and Kost 2014). Peran mahasiswa sangat sentral dalam berbagai aspek kehidupan, baik dalam bidang akademisi, politik, hukum dan sosial. Pada proses perguruan tinggi diharapkan mahasiswa dapat lebih memahami tentang metode pendidikan yang mengikuti perubahan semakin maju dari sebelumnya, dan karena sedang masa pandemi membuat pembelajaran di perguruan tinggi menjadi pembelajaran daring atau dalam jaringan, namun pada pembelajaran seperti ini kurangnya interaksi antara dosen saat memberikan pembelajaran kepada mahasiswa, perubahan tersebut membuat keterbatasan pemberian pembelajaran (Prawanti and Sumarni 2020), pada pembelajaran dalam jaringan juga calon pendidik diharuskan bisa berinovasi dalam memberikan pembelajaran seperti memberikan pembelajaran ilmu pengetahuan alam.

Ilmu pengetahuan alam (IPA) adalah ilmu untuk menanamkan dan mengembangkan pengetahuan, keterampilan sikap dan nilai ilmiah pada setiap manusia serta rasa mencintai dan menghargai kebesaran Sang Pencipta (Kurniawati 2017). Adapun peran IPA dalam pendidikan adalah untuk meningkatkan kepekaan mahasiswa terhadap lingkungan dan dapat menyelesaikan masalah dalam kehidupan terkait lingkungan sekitar (AMALLIA 2018), Dan tujuan IPA di Perguruan tinggi Khususnya di PGSD agar calon pendidik dapat memahami pembelajaran IPA sebagai bekal untuk terjun langsung ke sekolah dasar. Calon pendidik didorong lebih kreatif dan berinovasi untuk menciptakan pembelajaran yang sesuai dengan proses kegiatan belajar mengajar(Fatoni 2019), tetapi juga didukung dengan berinovasi menggunakan keterampilan proses sains, keterampilan proses sains sangat penting dimiliki oleh setiap calon pendidik. Keterampilan proses sains perlu dimiliki calon pendidik karena dengan keterampilan proses sains dapat lebih menggunakan daya pikir dan kreasi secara efektif.

Salah satu komponen yang membantu kegiatan pembelajaran adalah modul pembelajaran. Modul pembelajan dapat berupa cetak maupun elektronik atau biasa disebut dengan e-modul (Harta, Tenggara, and Kartasura 2014). Modul merupakan suatu paket belajar yang berkenaan dengan satu unit bahan pelajaran (Sungkono 2009), dan Modul harus disusun secara sistematis dan menarik supaya dapat menarik minat belajar siswa (Rizky Fitria 2018), Pengunaan dalam pembelajaran sangat sesuai untuk dapat menjawab tantangan era revolusi industri yang semua sudah serba digital, ISpring Suite merupakan salah satu komponen yang membantu kegiatan belajar mengajar (Martiningsih 2018), ISpring Suite merupakan software 
yang dapat mengubah file menjadi bentuk flash, dan karena sudah terinstal bisa langsung dipakai secara mudah oleh Microsoft Power Point (Wulandari 2020), Ispring suite dipakai karena lebih mudah digunakan untuk pembelajaran, dan juga Penggunaan produk pembelajaran berbasis ispring suite akan sangat membantu Pendidik dan calon pendidik berinteraksi di waktu senggang.

Penelitian yang dilakukan oleh (Indriani 2020) mengatakan bahwa penggunaan Microsoft Power Point dengan ispring suite berupa File LKPD dapat di unduh dan di edit pada tampilantampilan slide, peneliti mengembangkan dengan menjadikan suatu aplikasi yang dapat digunakan di android dan dijadikan sebagai sarana pembelajaran untuk meningkatkan motivasi dan kreativitas peserta didik.

Dalam penelitian sebelumnya, pengembangan e-modul menggunakan ispring suite masih belum menggunakan pembelajaran praktikum, sehingga pada penelitian ini akan dilaksanakan dengan menggunakan pembelajaran praktikum dalam kegiatan pembelajaran. Pengembangan e-modul dengan pembelajaran praktikum tentunya membantu baik dosen maupun mahasiswa untuk mampu mencapai tujuan belajar dan proses pembelajaran lebih bermakna bukan hanya sekedar membaca.

Oleh karena itu penelitian ini bertujuan untuk mengembangkan E-modul dengan menghadirkan sebuah Aplikasi pada mata kuliah konsep dasar IPA 1 materi organ pada tumbuhan berbasis ispring suite dan menguji validitasnya dengan cara hasil penilaian dan juga saran para ahli media, ahli materi dan respon mahasiswa melalui uji coba produk, diharapkan dari penelitian ini dapat meningkatkan motivasi dan antusias mahasiswa dalam pembelajaran jarak jauh dalam pembelajaran konsep dasar ipa 1 materi organ pada tumbuhan.

\section{Metode Penelitian}

Metode penelitian ini menggunakan metode (R\&D) Reseacrh and Devlopment, metode penelitian (Sugiono 2016) ini digunakan untuk menghasilkan suatu produk dan diuji ke efektifan produk tersebut, penelitian ini menggunakan model pengembangan yang mengacu pada model Addie (Analysis, design, development, Impementation dan evaluation) yang bertujuan untuk mengetahui apakah produk yang dihasilkan akan berguna pada pembelajaran konsep dasar IPA 1 materi organ pada tumbuhan semester 2 kelas 2B, penelitian ini dilaksanakan di kampus FKIP Uhamka Jakarta timur, ada tiga tahapan dalam penelitian ini, pertama validasi ahli materi terlebih dahulu, kedua validasi ahli media, dan terahir adalah respon mahasiswa pada saat menggunakan produk yang telah dibuat.

Karena menggunakan penelitian (R\&D) peneliti menggunakan model pengembangan yang mengacu pada model Addie (Yuniasih, Aini, and Widowati 2018) yang merupakan singkatan dari (Analysis, design, development, Impementation dan evaluation) atau bisa disebut dengan kata (analisis, rancangan, pengembangan, implementasi dan evaluasi), melalui tahapan-tahapan model model yang akan digunakan, pengembangan akan dimulai dari analisis sampai evaluasi, pada tahap analisis peneliti mencari masalah dan kebutuhan mahasiswa, analisis materi, dan tujuan yang dikembangkan suatu poduk. Pada tahap kedua adalah design yaitu tahapan pembuatan produk yang akan kita kembangkan, dengan merancang sesuatu perangkat pembelajaran dan merancang materi pembelajaran dan evaluasi 
hasil belajar. Dan juga menyusun konsep pembelajaran didalam bahan ajar yang akan dipakai serta dapat merancang metode evaluasi.

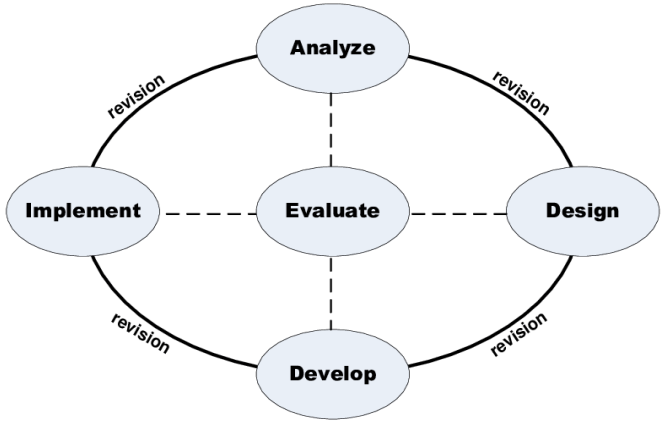

Gambar 2. Bagan Addie

Di dalam bahan ajar yang dirancang terdapat audio, audio visual, animasi, gambar, dan symbol. Tahapan ketiga yaitu development, Development merupakan tahapan pengembangan produk yang telah dibuat pada tahap desain menjadi tahapan nyata(Wartoyo 2019), pada saat mendesain hanya membuat rancangan yang akan di buat, pada tahap development membuat rancangan produk menjadi suatu kenyataan, yang meliputi kegiatan seperi Membuat animasi, gambar, video dan quiz menjadi suatu kenyataan.

Setelah selesai dan pembelajaran pada tahapan pengembangan produk sudah siap untuk digunakan, selanjutnya adalah tahapan implementasi, yaitu uji coba ke sasaran yang akan dituju yaitu mahasiswa semester 2, Ketika produk di uji coba bahan pembelajaran yang telah dirancang kemudian diterapkan pada situasi yang sebenarnya, dan dievaluasi kembali dan direvisi sehingga menghasilkan produk akhir yang siap digunakan(Tegeh and Kirna 2013). Tahap terahir adalah tahap evaluasi dimana setelah selesai di uji cobakan dapat kita akan mengetahui kekurangan dan kelebikan prodak tersebut diketahui kesalahan pada saat validator dan mahasiswa mengisi angket dan memberi saran untuk produk yang saya berikan agar menjadi prodak yang baik dan peneliti akan membuat memperbaiki segala kekurangan yang ada didalam prodak tersebut.

Pada pengumpulan data berikut saya menggunakan angket atau kuisoner, dan pengumpulan data tersebut dilakukan dengan cara menyebar pertanyaan tertulis maupun lewat teknologi yang sudah ada seperti melakukan hal tersebut melalui googlefrom, angket tersebut digunakan untuk mengukur kualitas dari media yang saya kembangkan, peneliti menggunakan skala likert, skala likert merupakan alat yang dapat digunakan untuk mengukur sikap dan pendapat seseorang, dalam menyusun angket penelitian untuk mengetahui kelayakan suatu produk yang dikembangkan (Nempung, Setiyaningsih, and Syamsiah 2015). Pembumpulan data pada pengembangan model ini menggunakan data kualitatif berupa masukan dari para ahli dan juga data kuantitatif yang merupakan data skor penilaian dari para ahli validator, data yang diperoleh dari hasil uji validitas oleh para ahli dihitung menggunakan skala likert dengan 1 sampai 4 poin.

Setelah dihitung menggunakan Skala Likert akan diukur tingkat validasi dari hasil penilaian oleh para ahli. Setelah menghitung persentase skor yang telah diperoleh, kemudian diukur dengan tingkat kelayakan prodak yang telah digunakan. 


\section{Hasil dan Pembahasan}

Produk hasil dari penelitian dan pengembangan ini modul keterampilan proses sains pada materi organ pada tumbuhan dalam bentuk aplikasi untuk android untuk mahasiswa semter 2 kelas 2B, Produk E-modul diberi nama "Organ Pada Tumbuhan" sebagai bahan ajar yang digunakan untuk materi organ pada tumbuhan, dalam e-modul ini berisikan konten materi, praktikum, video, dan quiz, hasil ahir dari e-modul berformat apk yang dapat diinstal pada smart phone android.

Tahap Analisis dilakukan dengan cara melakukan observasi pada mahasiswa semester dua PGSD di Universitas Muhammadiyah Prof. Dr. Hamka. Berdasarkan hasil observasi yang dilakukan, diketahui bahwa proses perkuliahan pada mata kuliah Konsep Dasar IPA 1 masih kurang memanfaatkan bahan ajar dalam bentuk E-modul. Sebagian besar dosen yang mengampu masih menggunakan bahan ajar cetak seperti buku teks dan Microsoft PowerPoint dengan presentasi sederhana, Dengan memanfaatkan kemajuan teknologi salah satunya smartphone membuat penggunaan modul pembelajaran kini sangat mudah dan dapat digunakan secara mandiri oleh semua kalangan khususnya mahasiwa dan dosen. Modul dapat digunakan dimana saja dan kapan saja karena bersifat fleksibel. Proses penyebaran aplikasi E-Modul ini cukup mudah karena dapat dikirim melalui WhatsApp grup lalu di unduh kemudian di install, Selain penggunaan pada smartphone, E-Modul juga dapat digunakan dengan menggunakan laptop atau PC oleh mahasiswa maupun dosen di ruang perkuliahan. Proses penyebaran E-Modul pada laptop di perlukan program tambahan untuk proses ekstraksi yaitu WinRAR. Setelah proses ekstrasi selesai, untuk memulai E-Modul pengguna harus membuka index dan E-Modul bisa digunakan.

Tahap Design adalah penyusun materi dari berbagai sumber dari buku konsep dasar ipa hingga buku organ tumbuhan, rancangan menggunakan media power point yang disesuaikan dengan pengguna aplikasi dan juga bahasan materi, E modul ini dibuat dengan bantuan Ispring suite dan website 2 APK builder sebagai pununjang media pada saat pembuatan Emodul ini, Berikut ini merupakan flowchart yang digunakan untuk menjelaskan aplikasi secara keseluruhan dapat dilihat pada.

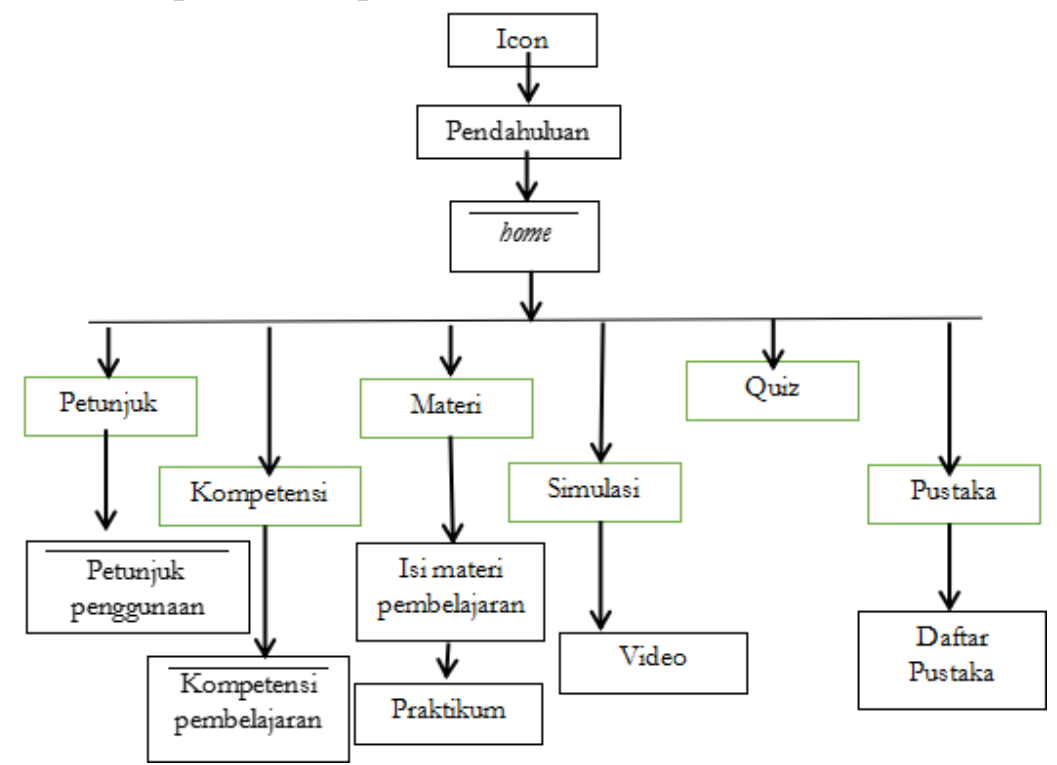

Gambar 2. Flowchart 
Tahap development adalah tahap pengembangan, setelah prodak selesai dikembangkan akan dilakukan tahap uji coba ke tim validasi ahli materi dan validasi ahli media, ahli materi adalah dosen yang berkompeten dalam pendidikan biologi, dan ahli media merupakan dosen yang ahli dalam bidang media pembelajaran dan rekayasa perangkat lunak. Hasil Validasi ahli materi dapat dilihat pada tabel 1.

Tabel 1. Hasil Validasi Ahli Materi

\begin{tabular}{ccc}
\hline Aspek & Ahli Materi & \\
\hline Tampilan & $93 \%$ & \\
Pembelajaran & $94 \%$ & Kategori \\
Evaluasi & $100 \%$ & \\
\hline Rata-rata & $94 \%$ & Sangat Baik
\end{tabular}

Hasil validasi dari ahli materi rata-rata keseluruhan pada tiap aspek dari validator mendapatkan skor presentase $94 \%$ dan peroleh aspek paling kecil yaitu pada aspek tampilan dengan skor presentase $93 \%$ dan perolehan terbesar pada aspek Evaluasi dengan presentase $100 \%$, untuk validasi ahli media dapat dilihat pada tabel 2

Tabel 2. Hasil Validasi Ahli Media

\begin{tabular}{ccc}
\hline Aspek & Ahli Media & \\
\hline Tampilan & $80 \%$ & \\
Tulisan & $100 \%$ & Kategori \\
Rekayasa & $92 \%$ & \\
Preangkat Lunak & & Sangat Baik
\end{tabular}

Hasil validasi dari ahli materi rata-rata keseluruhan pada tiap aspek dari validator mendapatkan skor presentase $89 \%$ dan peroleh aspek paling kecil yaitu pada aspek Rekayasa perangkat lunak dengan skor presentase $92 \%$ dan perolehan terbesar pada aspek Tulisan dengan presentase $100 \%$.

Berdasarkan hasil validasi dari ahli para ahli materi dan media dan tiap aspek rata-rata memiliki kategori yang sangat baik. Hal ini dikarenakan aplikasi yang dibuat telah disesuaikan isi konten pada materi semester 2 PGSD yang dimuat dengan tampilan menarik dan memudahkan bagi pengguna. Selain itu aolikasi sudah dapat dapat berjalan secara normal tanpa gangguan saat digunakan.

Tahap implementasi dilakukan dengan menyebarkan e-modul kepada mahasiswa semester dua kelas 2B PGSD FKIP UHAMKA. Angket yang digunakan pada menggunakan skala Likert untuk penilaian yaitu angka satu sampai dengan empat. Aspek yang diujikan kepada mahasiswa yaitu aspek tampilan, aspek tulisan, aspek rekayasa perangkat lunak dan aspek materi. Sebelum modul digunakan, mahasiswa diminta kesediaannya untuk mengunduh aplikasi E-Modul pada file yang disebarkan melalui WhatsApp, Uji respon mahasiswa terhadap produk dapat dilihat pada tabel 3. 
Tabel 3. Respon Hasil Mahasiswa

\begin{tabular}{ccc}
\hline Aspek & Ahli Media & \\
\hline Tampilan & $88 \%$ & \\
Tulisan & $91 \%$ & Kategori \\
Rekayasa & $88 \%$ & \\
Preangkat Lunak & & \\
Materi & $93 \%$ & Sangat Baik
\end{tabular}

Ditinjau dari aspek tampilan sebesar 88\% dengan katagori sangat baik dengan desain dan tampilan interface yang dibuat menarik. Ditijau dari aspek tulisan sebesar $91 \%$ dengan katagori Sangat baik, perlu diberikan perbaikan karena tulisan yang kurang jelas untuk dilihat pada materi didalam E-Modul, tetapi Bahasa yang digunakan mudah untuk dipahami. Ditinjau dari aspek rekayasa perangkat lunak sebesar 88\% dengan katagori sangat baik, produk mudah untuk digunakan dan diakses oleh semua mahasiswa yang menggunakan Android. Dan aspek materi sebesar 93\% dengan kategori sangat baik, materi yang sesuai sehingga mahasiswa mudah memahami materi dan penggunaan Bahasa pada materi adalah Bahasa yang berkaitan dengan kehidupan sehari-hari. Secara keseluruhan kualitas media pembelajaran yang diuji cobakan pada mahasiswa semester dua sebesar $87 \%$ dengan katagori sangat baik sehingga dapat dijadikan bahan ajar mandiri oleh mahasiswa.

Setelah tahap implementasi dilakukan dengan menyebarkan e-modul kepada mahasiswa, dilakukan tahap evaluasi. Apabila dalam uji coba masih menemukan kekurangan, maka perlu dilakukan tahap evaluasi kembali, dimana peneliti melakukan penyempurnaan modul elektronik yang dikembangkan. Pada evaluasi produk akhir, dilakukan agar modul elektronik yang telah dikembangkan dapat digunakan dengan mudah oleh mahasiswa sebagai bahan ajar mandiri.

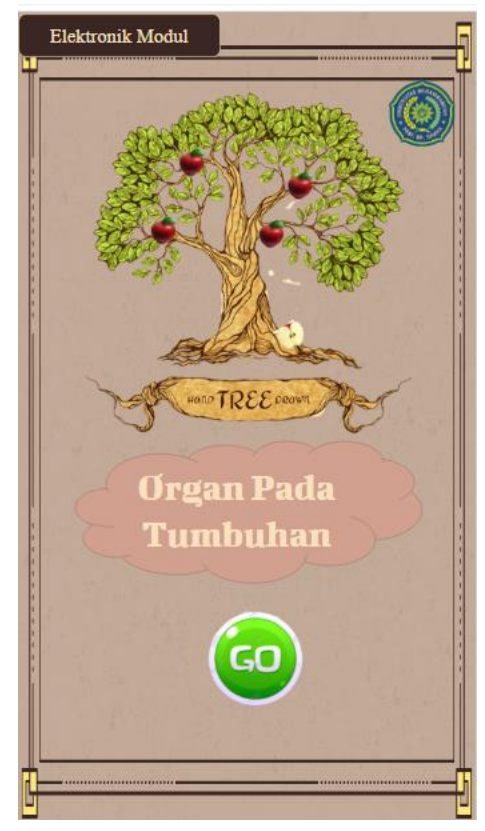

Gambar 3. Aplikasi Organ Pada Tumbuhan 
Hasil pengembangan yang telah dilakukan maka peneliti melakukan validasi kepada ahli media dan ahli materi untuk mengetahui kelayakan pada media yang terdiri dari penilaian,Kritik dan Saran. Hal ini dilakukan sebagai bahan perbaikan media. Penilaian hasil validasi mendapatkan kategori layak yang dapat dilihat pada tabel. Penelitian ini sejalan yang dilakukan (Yuniasih, Aini, and Widowati 2018) hasil dari validasi tersebut media pembelajaran E-modul berbasis keterampilan proses sains dapat digunakan sebagai pendukung dari proses pembelajaran yang bervariasi.

Kualitas bahan ajar media aplikasi dinilai layak untuk digunakan berdasarkan hasil validasi ahli materi, media dan respon peserta Mahasiswa. Aplikasi bahan ajar menampilkan seacara menyeluruh mengenai hal yang disampaikan di dalam proses pembelajaran seperti materi,pembahasan, Praktikum serta Quiz yang mampu memfasilitasi dan memberikan pengalaman belajar baru bagi Mahasiswa baik pemebelajaran dilakukan secara dalam jaringan maupun tatap muka. Hal ini bermakna bahwa Mahasiswa harus mendapatkan ilmu secara utuh mengenai kompetensi yang harus dicapai dalam proses pembelajaran. Hal ini menunjukan bahwa jika bahan ajar dikembangan sesuai kebutuhan dan dimanfaatkan secara benar maka akan menciptakan bahan ajar yang dapat meningkatkan mutu pembelajaran dan antusias Mahasiswa (Nurhairunnisah and Sujarwo 2018).

Aplikasi pembelajaran dapat digunakan sebagai alternatif pada pembelajaran IPA materi Organ tumbuhan secara daring. Untuk memahami pembelajaran IPA materi organ tumbuhan tidak hanya didapat melalui membaca saja. Baik ketika tatap muka maupun pembelejaran daring, Pendidil harus mampu memberikan penjelasan secara konkrit dengan bendabenda/tumbuhan yang nyata sehingga dapat dipahami mahasiswa. Hal ini sejalan dengan tingkat perkembangan intelektual menurut Piaget, Yang sebaiknya dimulai dari penyajian materi secara konkrit menuju semi konkrit dan abstrak menggunakan Tumbuhan Tumbuhan (HIMMAH 2017)

Media merupakan alat perantara pendidik dalam menyampaikan materi kepada siswa. Media pembelajaran dapat dikembangkan pada pembelajaran dalam jaringan dapat memberikan situasi dan hal baru bagi siswa salah satunya melalui aplikasi pembelajaran. Aplikasi pada umumnya memiliki definisi sebagai suatu perangkat alat terapan yang berfungsi sesuai kemampuan yang dimiliki oleh aplikasi. Aplikasi juga memiliki arti suatu program yang dapat digunakan untuk menjalankan suatu perintah kegiatan bagi pengguna aplikasi (Harta, Tenggara, and Kartasura 2014)

Dalam pembelajaran saat ini, pembelajaran berbasis android sangat cocok diterapkan pada Pembelajaran Jarak Jauh (PJJ) Maupun Pemebelajaran secara tatap muka. Secara umum Android merupakan sebuah sistem yag dapat dioperasikan untuk smartphone. Sistem android dapat digambarkan sebagai penghubung pada perangkat berupa handphone salah satunya kepada pengguna yang mengoprasikannya, Sebab itu pengguna dapat secara mudah berintraksi dengan perangkat serta menggunakan aplikasi-aplikasi yang tersedia pada perangkat (Kuswanto and Radiansah 2018). Dalam hal ini sejalan dengan pesera didik yang dapat mengoprasikan smartphonennya untuk melakukan kegiatan pembelajaran yag menyenangkan diamanapun dan kapanpun mereka ingin belajar. karena sifat aplikasi yaitu dapat memudahkan siswa mengakses pembelajaran melalui smartphone.

Berdasarkan nilai total kevalidan maka media pembelajaran berbasis Power Point Ispring Suite layak untuk digunakan kepada subjek penelitian. Nilai valid yang diperoleh dengan 
ketercapaian indikator penilaian berupa kesesuaian penyajian materi pembelajaran, dukungan media terhadap penanaman konsep, kesesuaian materi pembelajaran dengan tujuan pembelajaran, kebenaran uraian materi pembelajaran, urutan penyajian materi pembelajaran, kesesuaian gambar dan animasi dengan uraian materi pembelajaran, kesesuaian Evaluasi berupa Quiz dengan tujuan pembelajaran, dan kejelasan uraian materi pembelajaran. ada beberapa kelebihan dalam pembuatan e-modul, diantaranya 1.) Aplikasi E-Modul merupakan modul pembelajaran pada mata kuliah Konsep Dasar IPA 1 yang dapat diakses pada smartphone Android dengan pemakaian yang cukup mudah dengan tampilan menarik, 2.) Aplikasi E-Modul merupakan modul pembelajaran yang bersifat tidak terbatas ruang dan waktu, 3.) Aplikasi E-Modul merupakan inovasi modul pembelajaran dimasa perkembangan teknologi 4.0 dengan menggunakan teknologi smartphone. Perangkat pembelajaran dikatakan valid jika penilaian ahli menunjukkan bahwa pengembangan perangkat tersebut memiliki konsistensi internal antara setiap aspek yang dinilai yakni keterkaitan antara komponen dalam perangkat dikemukakan oleh (Hala 2015), bahwa Jika keseluruhan aspek penilaian telah mencapai kriteria kevalidan, maka media yang dikembangkan dinyatakan layak digunakan dalam pembelajaran,

\section{Kesimpulan}

Berdasarkan perolehan data yang sudah dilakukan mendapatkan kesimpulan Pengembangan modul berbasis software iSpring Suite menggunakan model ADDIE yang di uji cobakan pada mahasiswa semester 2 kelas 2B PGSD FKIP UHAMKA. Hasil ini menunjukan e-modul ini layak untuk digunakan sebagai bahan ajar untuk mata kuliah konsep dasar IPA 1 materi organ pada tumbuhan semester 2 kelas 2B UHAMKA. Aplikasi e-modul ini menjadi inovasi baru untuk proses belajar belajar dikelas maupun dirumah, aplikasi mudah digunakan bagi pengguna android dan memiliki cakupan materi yang cukup baik, sehingga dengan adanya aplikasi e-modul interaktif ini dapat meningkatkan produktivitas dengan minim tenaga.

\section{Daftar Pustaka}

AMALLIA, PRAJNA. 2018. "Pengembangan Media Poster Pada Pembelajaran Ipa Materi CiriCiri Lingkungan Sehat Dan Lingkungan Tidak Sehat Siswa Kelas III Sdn Lirboyo." New England Journal of Medicine 372(2): 2499-2508.http://dx.doi.org/10.1016/j. Ahttps://doi.org/10.1007/s00401-018-1825

http://www.ncbi.nlm.nih.gov/pubmed/27157931.

Fatoni, Andi. 2019. “Keterampilan Proses Sains Siswa Kelas IV Melalui Metode Praktium Pada Mata Pelajaran IPA Di MI M UL Anwar." http:/ / repository.radenintan.ac.id/6807/1/SKRIPSI.pdf.

Hala, Yusminah. 2015. "Pengembangan Perangkat Pembelajaran Biologi Berbasis Pendekatan Saintifik Pada Konsep Ekosistem Bagi Siswa Sekolah Menengah Pertama." Journal of Educational Science and Technology (EST) 1(3): 85-96.

Harta, Idris, Sulawesi Tenggara, and Pabelan Kartasura. 2014. “Pengembangan Modul Pembelajaran Untuk Meningkatkan Pemahaman Konsep Dan Minat SMP." Pengembangan Modul Pembelajaran untuk Meningkatkan Pemahaman Konsep dan Minat SMP 9(2): 161-74.

HIMMAH, FAIQOTUL. 2017. “Pengembangan Multimedia Interaktif Menggunakan Ispring 
Suite 8 Pada Sub Materi Zat Aditif Untuk Meningkatkan Hasil Belajar Siswa Smp Kelas Viii." Pensa: Jurnal Pendidikan Sains 5(2): 73-82.

Indriani, Verina Meydia. 2020. “Pengembangan Lembar Kerja Peserta Didik (LKPD) Berbasis Microsoft Power Point Pada Subtema Keberagaman Budaya Bangsaku Kelas IV Sekolah Dasar." Jpgsd 8: 1044-52. https://ejournal.unesa.ac.id/index.php/jurnal-penelitianpgsd/article/view/36681.

Kurniawati, Fitra. 2017. "Penerapan Langkah-Langkah Model Assure Dalam Pemilihan Media Mata Pelajaran Ipa Oleh Guru Sd Negeri Kelas Rendah." Вестник Росздравнадзора 4(April): 9-15.

Kuswanto, Joko, and Ferri Radiansah. 2018. "Media Pembelajaran Berbasis Android Pada Mata Pelajaran Sistem Operasi Jaringan Kelas XI.” Jurnal Media Infotama 14(1).

Martiningsih, Rr. 2018. "MENGGUNAKAN APLIKASI ISPRING SUITE 8 The Increase of Set Learning Outcomes By Using iSpring Suite 8 Aplication.” Teknodik 22(1): 1-13.

Nempung, Tibertius, Timor Setiyaningsih, and Nur Syamsiah. 2015. "Otomatisasi Metode Penelitian Skala Likert Berbasis Web." (November): 1-8.

Nurhairunnisah, Nurhairunnisah, and Sujarwo Sujarwo. 2018. “Bahan Ajar Interaktif Untuk Meningkatkan Pemahaman Konsep Matematika Pada Siswa SMA Kelas X.” Jurnal Inovasi Teknologi Pendidikan 5(2): 192-203.

Prawanti, Lia Titi, and Woro Sumarni. 2020. "Kendala Pembelajaran Daring Selama Pandemic Covid-19." Prosiding Seminar Nasional Pascasarjana UNNES: 286-91.

Priyanthi, Kadek Aris, M.Si. Dr. Ketut Agustini, S.Si, and M.Cs Gede Saindra Santyadiputra, S.T. 2017. "Pengembangan E-Modul Berbantuan Simulasi Berorientasi Pemecahan Masalah Pada Mata Pelajaran Komunikasi Data (Studi Kasus : Siswa Kelas XI TKJ SMK Negeri 3 Singaraja)." Kumpulan Artikel Mahasiswa Pendidikan Teknik Informatika (KARMAPATI) 6(1): 40.

Rizky Fitria. 2018. "PENGEMBANGAN BAHAN AJAR MATEMATIKA BERBANTUAN APLIKASI MICROSOFT MATHEMATICS PADA SISWA KELAS XI." (21): 1-9.

Sataloff, Robert T, Michael M Johns, and Karen M Kost. 2014. “Prestasi Belajar Dasar Akutansi Keuangan 1 Ditinjau Dari Keterampilan Mengajar Dosen Dan Minat Belajar Mahasiswa Pendidikan Akuntansi Angkatan 2012 Universitas Muhammadiyah Surakarta." : 1-12. http://eprints.ums.ac.id/27452/2/BAB_I.pdf.

Sugiono. 2016. Metode Penelitian Kuantitatif, Kualitatif, Dan RED. Bandung: ALFABET.

Sungkono, Sungkono. 2009. “Pengembangan Dan Pemanfaatan Bahan Ajar Modul Dalam Proses Pembelajaran." Majalah Ilmiah Pembelajaran 5(1).

Tegeh, I Made, and I Made Kirna. 2013. "Pengembangan Bahan Ajar Metode Penelitian Pendidikan Dengan ADDIE Model." Jurnal IKA 11(1): 16. https:/ / ejournal.undiksha.ac.id/index.php/IKA/article/view/1145.

Wartoyo, Anita Trisiana. 2019. “Desain Pengembangan Model Pembelajaran Pendidikan Kewarganegaraan Melalui ADDIE Model Untuk Meningkatkan Karakter Mahasiswa Di Universitas Slamet Riyadi Surakarta." Jurnal PKn Progresif 11(1): 313-30.

Wulan, Dyah Ayu Noor, and Sri Muliati Abdullah. 2014. "Prokrastinasi Akademik Dalam Penyelesaian Skripsi." Jurnal Sosio - Humaniora 5(1): 1-25. file:/ / C:/Users/anggirahmas/Downloads/136-379-1-PB.pdf. 
Wulandari. 2020. “Pengembangan Modul Berbasis Software iSpring Suite 9 Pada Mata Kuliah Konsep Dasar IPA 1 Materi Ekosistem Bagi Mahasiswa Program Studi PGSD FKIP UHAMKA."

Yuniasih, Nury, Ririn Nur Aini, and Retno Widowati. 2018. "Pengembangan Media Interaktif Berbasis Ispring Materi Sistem Pencernaan." Jip 8(2): 85-94. 